\title{
Chemical Characterization of Asturian Cider
}

\author{
Anna Picinelli,* Belén Suárez, J avier Moreno, Roberto Rodríguez, Lourdes Mª Caso-García, and \\ J uan J osé Mangas
}

Departamento de Sidras y Derivados, SERIDA, 33300 Villaviciosa, Asturias, Spain

\begin{abstract}
Ninety-four samples of Asturian natural cider were analyzed for titratable and volatile acidities, $\mathrm{pH}$, al coholic, total polyphenol, and acidic polysaccharide contents, nonvolatile acids, polyalcohols, residual sugars, and major volatile compounds. A partial least-squares regression analysis (PLR-1) was performed to correlate the chemical composition and the origin of the raw material, the cider samples being grouped into two categories: an "odd" class, cider made from foreign apples (1995 and 1997), and an "even" class, ciders made from Asturian apples (1996 and 1998). The mathematical model has a multiple linear correlation coefficient of $80 \%$.
\end{abstract}

Keywords: Alcoholic beverages; cider composition; HPLC; GC

\section{INTRODUCTION}

In Europe, the term "cider" refers to the fermented beverage obtained from apples. Cider making constitutes an important industry, the greatest producer being the U.K., followed by Ireland, France, and Spain. Asturias, which is located on the Atlantic coast of northern Spain, is the country's leading cider-producing region (ca. $80 \%$ of the total) (IFR, 1997).

The Spanish Alimentary Code (BOE, 1979) defines cider as a drink made from the partial or complete fermentation of the juice of fresh apples or concentrated apple juice, with a minimum alcoholic proof of $4 \%(\mathrm{v} / \mathrm{v})$. This definition includes two different kinds of drinks. The first, sparkling cider, is made from concentrated apple juice and/or fresh apple must, the addition of sugars and carbon dioxide being permitted, as well as the use of different stabilization processes. The production of sparkling cider in Asturias is ca. 50 million liters per year.

The second beverage, referred to as "natural cider", is made according to traditional methods, which imply, among other practices (such as the prohibition of addition of sugars and $\mathrm{CO}_{2}$ ), the exclusive use of juices obtained from the pressing of cider apples. This limitation for the natural cider-making process affects its production, which depends largely on the availability of the raw material. In Asturias, the cider apple tree is a biennial crop, meaning that every two years cider is basically made from Asturian varietal must (odd years), while in the even years, the raw material is provided by other Spanish regions, Galicia, and other countries, France and Eastern Europe. Despite this situation, natural cider making is an important industry, with an average yearly production of close to 40 million liters.

Asturian natural cider presents differences when compared to F rench or English cider. It is dry and acidic, with a balanced aroma described as fresh, cidery, and vinegary (Picinelli, 1999), while French cider is bittersweet with apple-like flavors. Most of the cider sold in the U.K. is a clear, carbonated product with varying degrees of sweetness and an al cohol content that ranges from $1.2 \%$ to $8.5 \%$ (Lea, 1995).
The kind and dynamics of the populations of microorganisms usually present during the alcoholic and mal olactic fermentation of Asturian natural cider have been studied and characterized by our research team (Cabranes et al., 1990, 1991, 1997; Salih et al., 1990). We have also studied the changes in sugars, organic acids, and major volatile compounds during the fermentation of apple must and their influence on the cidermaking technology employed (Blanco et al., 1991; Mangas et al., 1993, 1994). However, there is a lack of written information on the chemical composition of commercial Asturian natural cider. Most of the information available on cider composition comes from the work done at the Long Ashton Research Center until the 1980s, e.g., volatile profiles (Williams and May, 1981; Williams and Tucknott, 1971, 1978) and procyanidins (Lea and Timberlake, 1974).

In this paper we present the chemical composition of Asturian natural ciders elaborated during the last four years and the influence of the raw material (geographic origin).

\section{MATERIALS AND METHODS}

Samples. Natural cider samples (94) were collected from their respective cider-makers' cellars, analyzed for global parameters, and frozen $\left(-20^{\circ} \mathrm{C}\right)$ until instrumental analyses.

Global Parameters. Total and volatile acidities, $\mathrm{pH}$, and $\mathrm{SO}_{2}$ and al coholic contents were measured according to official methods (AOAC, 1984). Total polyphenol analyses were conducted using the Folin-Ciocalteu method (Montreau, 1972); acidic polysaccharides were obtained by the method optimized el sewhere (Mangas et al., 1999).

Sugars. Analyses of residual sugars and polyalcohols (fructose, glucose, sucrose, glycerol, and sorbitol) were performed on an HPLC system (Waters Chromatography Division, Milford, MA) equipped with a 510 pump, a WISP 712 automatic injector, provided with a temperature controller, a 410 refractive index detector, and a Millenium v.2.0 software module. Separations were carried out on a cationic exchange column (Sugar-Pak I, Waters) according to the method optimized by Blanco et al. (1988).

Nonvolatile Acids. Organic acids (shikimic, malic, Iactic, acetic, succinic, and ascorbic) were analyzed on the same HPLC system, though provided with a DAD 996 diode-array detector. Separations were carried out on a Spherisorb ODS-2 
Table 1. Mean Values for Total and Volatile Acidities, pH, Alcohol Content, Total Polyphenols, and Acidic Polysaccharides in Asturian Natural Cidersa

\begin{tabular}{|c|c|c|c|c|c|c|c|}
\hline consumption season & & $\mathrm{TA}^{\mathrm{b}}$ & $\mathrm{VA}^{\mathrm{c}}$ & $\mathrm{pH}$ & $\begin{array}{l}\text { alcoholic } \\
\text { content }^{d}\end{array}$ & TPe & $A P^{f}$ \\
\hline \multirow[t]{4}{*}{$1995(n=18)$} & mean & $3.72^{a}$ & $1.69^{b}$ & $3.77^{a}$ & $6.4^{c}$ & $1.3^{d}$ & \\
\hline & SD & 0.41 & 0.57 & 0.14 & 0.4 & 0.4 & \\
\hline & $\max$ & 4.35 & 2.66 & 4.17 & 6.9 & 2.0 & \\
\hline & $\min$ & 3.00 & 0.71 & 3.62 & 5.8 & 0.7 & \\
\hline \multirow[t]{4}{*}{$1996(n=31)$} & mean & $3.80^{a}$ & $1.37^{a}$ & $3.81^{a}$ & $6.5^{c}$ & $1.0^{\mathrm{b}}$ & \\
\hline & SD & 0.49 & 0.53 & 0.11 & 0.2 & 0.2 & \\
\hline & $\max$ & 4.78 & 2.65 & 3.93 & 7.0 & 1.4 & \\
\hline & $\min$ & 2.76 & 0.52 & 3.54 & 6.1 & 0.5 & \\
\hline \multirow[t]{4}{*}{$1997(n=25)$} & mean & $3.81^{a}$ & $1.47^{a}$ & $3.85^{c}$ & $6.1^{\mathrm{b}}$ & $1.0^{\mathrm{b}}$ & $19.4^{a}$ \\
\hline & SD & 0.40 & 0.42 & 0.07 & 0.2 & 0.2 & 12.3 \\
\hline & $\max$ & 4.78 & 2.76 & 4.00 & 6.4 & 1.4 & 61.0 \\
\hline & $\min$ & 2.60 & 0.83 & 3.72 & 5.9 & 0.6 & 5.4 \\
\hline \multirow[t]{4}{*}{$1998(n=20)$} & mean & $3.56^{a}$ & $1.60^{\mathrm{a}}$ & $3.75^{a}$ & $5.3^{a}$ & $0.8^{a}$ & $41.9^{b}$ \\
\hline & SD & 0.33 & 0.43 & 0.07 & 0.2 & 0.2 & 24.6 \\
\hline & $\max$ & 4.17 & 2.64 & 3.95 & 5.7 & 1.2 & 118.7 \\
\hline & $\min$ & 2.82 & 0.74 & 3.65 & 5.0 & 0.5 & 17.6 \\
\hline
\end{tabular}

\footnotetext{
${ }^{a}$ Results of the Duncan test. Values with the same superscript letter are not significantly different at the $5 \%$ level. ${ }^{\mathrm{b}}$ Total acidity (g of sulfuric acid/L). ${ }^{c}$ Volatile acidity (g of acetic acid/L). ${ }^{d}$ Alcoholic content (\% v/v at $20{ }^{\circ} \mathrm{C}$ ). ${ }^{e}$ Total polyphenols ( $\mathrm{g}$ of tannic acid/L). ${ }^{\mathrm{f}} \mathrm{Acidic}$ polysaccharides (mg of galacturonic acid/L).
}

column $(250 \times 0.46 \mathrm{~mm}$ i.d., $3 \mu \mathrm{m}$, Teknokroma, Barcelona, Spain) using $0.01 \mathrm{M}$ potassium dihydrogen phosphate $(\mathrm{pH} 2.6)$ in isocratic mode $(0.5 \mathrm{~mL} / \mathrm{min})$. Detection was performed at 206 and $245 \mathrm{~nm}$. The temperature of analysis was $40{ }^{\circ} \mathrm{C}$. Samples were filtered through a $0.45 \mu \mathrm{m}$ cellul ose acetate filter and injected (10 $\mu \mathrm{L})$.

Volatile Compounds. Analyses of major volatile compounds (acetaldehyde, ethyl acetate, methanol, 1-propanol, isobutanol, 1-butanol, amylics, ethyl lactate + hexanol, and 2-phenylethanol) were carried out by GC using a 5890 HewlettPackard system provided with a flame ionization detector (FID) and a TR-FFAP column $(30 \mathrm{~m} \times 0.53 \mathrm{~mm}, 1 \mu \mathrm{m}$ thickness phase) protected with a $1 \mathrm{~m}$ TR retention gap (Teknokroma, Barcelona, Spain), inserted into a split/splitless injector (splitless time $1 \mathrm{~min}$ ), with helium (3 psi) as carrier gas. The temperature gradient was as follows: isothermal step at $40{ }^{\circ} \mathrm{C}$ for $4 \mathrm{~min}$ and then programmed at $4{ }^{\circ} \mathrm{C} / \mathrm{min}$ to $60^{\circ} \mathrm{C}$, and at $10^{\circ} \mathrm{C} / \mathrm{min}$ to $220^{\circ} \mathrm{C}$. The injector temperature was 240 ${ }^{\circ} \mathrm{C}$, and the detector was operated at $275{ }^{\circ} \mathrm{C}$. Quantification was carried out by the external standard method. Samples were filtered through a $0.45 \mu \mathrm{m}$ cellulose acetate filter and injected $(1 \mu \mathrm{L})$.

Statistical Analysis. The data were analyzed for the difference of means between years using the SPSS program (SPSS, 1994), a significance level of $5 \%$ being selected. Subsequently, the ciders were categorized for multivariate analyses into two groups according to the years of consumption: in the "odd" class, natural ciders made from foreign apples (1995 and 1997) and, in the "even" class, ciders made from Asturian apples (1996 and 1998). Thus, a one-factor experiment (category) with two replicates in each group (years) was considered. Partial least-squares regression analyses (PLSR) were performed with the PARVUS statistical package (Forina et al., 1988). A data matrix was structured with 94 rows representing cider samples, and 22 columns representing the chemical variables (total and volatile acidities, alcoholic content, total polyphenols, pH, malic, shikimic, lactic, acetic, and succinic acids, fructose, glycerol, sorbitol, acetaldehyde, ethyl acetate, methanol, 1-propanol, isobutanol, 1-butanol, amylics, ethyl lactate + hexanol, and 2-phenylethanol). A binary response $(Y)$ was defined: $Y=1$ for the odd class $(O)$, and $Y=2$ for the even class (E). The data were autoscaled before statistical treatment.

\section{RESULTS AND DISCUSSION}

Samples were analyzed over a four year period in which ciders elaborated from Asturian apples in the odd years (consumed in 1996 and 1998) and ciders made from blends of Galician and French apples in the even years (consumed in 1995 and 1997) were included. The values for titratable and volatile acidities, $\mathrm{pH}$, and alcohol, total polyphenol, and acidic polysaccharide contents are presented in Table 1, together with the results of the analyses of the difference of means (Duncan test, with a confidence interval of $5 \%$ ).

Polyphenols are important for flavor and for avoiding microbiological spoilage. Due to the dedine in the consumption of cider in the past in Asturias, many cider apple orchards were abandoned or substituted by dessert apple varieties, thus contributing to the lack of valuable bitter varieties, even though the usual traditional orchard practices, with poor nitrogen fertilization, yield high phenolic levels in apples (Lea and Beech, 1978). Mean values were significantly higher for samples from 1995, while those from 1998 were the lowest. However, no significant differences were found between the other two groups of ciders (1996 and 1997).

Acidic polysaccharides or pectin contents varied widely. Their presence in ciders is usually related to the apple ripeness (Mangas et al., 1998), the prefermentative technology, and the action of microorganisms during the biotransformation of fruit. The acidic polysaccharide level is one of the most relevant variables exerting a great influence on cider foaming properties (Mangas et al., 1999), these latter being important aspects of the sensory evaluation of ciders. Significant differences for mean values were observed between years $(t=3.87, p$ $<0.001$ )

Ethanol is the major volatile component of alcoholic beverages. In ciders, it gives body, reduces apparent acidity, increases sweetness, and has an overall smoothing effect on other taste characteristics (Williams, 1972). The al coholic content in samples ranged between $5.0 \%$ and $7.0 \%(\mathrm{v} / \mathrm{v})$ (Table 1). Values for the 1998 consumption season were the lowest. These values might be related to climatic conditions during the harvest year (1997). The levels of rainfall in Asturias from J une to September (maximum development of the fruit) in 1997 were $20 \%$ higher than those observed in the other years.

One characteristic of Asturian natural cider is the relatively high value of volatile acidity. However, high volatile acidity is not always objectionable, being appreciated in some cases (Picinelli, 1999). In contrast, other ciders presented an unpleasant acetic taint with 
Table 2. Organic Acid and Residual Sugar (g/L) Contents in Asturian Natural Cidersa

\begin{tabular}{|c|c|c|c|c|c|c|c|c|c|}
\hline consumption season & & Shikimic acid ${ }^{b}$ & malic acid & lactic acid & acetic acid & succinic acid & fructose & glycerol & sorbitol \\
\hline \multirow{4}{*}{$1995(n=18)$} & mean & $6.67^{a}$ & $0.02^{a}$ & $4.41^{d}$ & $1.53^{c}$ & $0.90^{d}$ & $0.17^{a}$ & $3.21^{a}$ & $5.99^{c}$ \\
\hline & SD & 10.47 & 0.02 & 0.61 & 0.52 & 0.11 & 0.29 & 1.30 & 0.54 \\
\hline & $\max$ & 43.48 & 0.10 & 5.4 & 2.4 & 1.24 & 1.04 & 4.99 & 7.04 \\
\hline & $\min$ & ND & ND & 3.48 & 0.68 & 0.77 & ND & 0.52 & 5.20 \\
\hline & mean & $5.96^{a}$ & $0.11^{\mathrm{a}}$ & $3.66^{c}$ & $1.03^{a}$ & $0.17^{a}$ & $0.94^{d}$ & $3.15^{a}$ & $6.38^{d}$ \\
\hline \multirow[t]{3}{*}{$1996(n=31)$} & SD & 6.69 & 0.53 & 0.49 & 0.43 & 0.26 & 0.99 & 1.33 & 0.55 \\
\hline & $\max$ & 29.12 & 2.94 & 4.8 & 2.0 & 0.95 & 3.09 & 4.98 & 7.14 \\
\hline & $\min$ & ND & ND & 1.92 & 0.18 & ND & ND & 0.12 & 5.27 \\
\hline \multirow[t]{4}{*}{$1997(n=25)$} & mean & $2.66^{a}$ & $0.11^{a}$ & $3.19^{a}$ & $1.32^{\mathrm{b}}$ & $0.53^{b}$ & $0.15^{a}$ & $3.20^{\mathrm{a}}$ & $5.53^{\mathrm{b}}$ \\
\hline & SD & 2.16 & 0.07 & 0.45 & 0.4 & 0.12 & 0.16 & 1.09 & 0.51 \\
\hline & $\max$ & 6.90 & 0.24 & 4.5 & 2.22 & 0.77 & 0.58 & 5.12 & 6.56 \\
\hline & $\min$ & ND & ND & 2.29 & 0.4 & 0.33 & ND & 1.39 & 4.47 \\
\hline \multirow[t]{4}{*}{$1998(n=20)$} & mean & $5.91^{a}$ & $0.02^{a}$ & $3.34^{a}$ & $1.37^{\mathrm{b}}$ & $0.50^{\mathrm{b}}$ & $0.40^{a}$ & $2.59^{a}$ & $4.46^{a}$ \\
\hline & SD & 6.05 & 0.03 & 0.47 & 0.32 & 0.06 & 0.76 & 1.73 & 0.85 \\
\hline & $\max$ & 22.61 & 0.09 & 4.41 & 1.88 & 0.58 & 3.26 & 5.78 & 5.37 \\
\hline & $\min$ & ND & ND & 2.53 & 0.63 & 0.39 & ND & ND & 1.97 \\
\hline
\end{tabular}

a Results of the Duncan test. Values with the same superscript letter are not significantly different at the $5 \%$ confidence level. $\mathrm{b}$ mg/L . $\mathrm{ND}=$ not detected.

values of volatile acidity lower than $0.80 \mathrm{~g} / \mathrm{L}$, possibly due to the presence of other volatile acids, mainly shortchain fatty acids (Williams and Tucknott, 1971). Apparently, acetic acid is more penetrating in thin ciders of low acidity than in a full-bodied, fairly acidic one (Whiting, 1973).

Table 2 summarizes the residual sugar, polyalcohol, and organic acid contents. Of the sugars analyzed (glucose, sucrose, and fructose), only fructose was found, with mean values lower than $1 \mathrm{~g} / \mathrm{L}$, since fermentation is always complete. A sweet taste is considered as a defect in Asturian natural cider; thus, great concern is taken by cider makers to guarantee the consumption of the sugars present in the must. Mean values for fructose were significantly higher in the ciders from 1996.

Concentrations for polyalcohols such as sorbitol and glycerol varied greatly, in accordance with expected values (Lee and Wrolstad, 1988). Sorbitol is the main polyalcohol synthesized in the leaves of apple trees and converted into sugars in the fruit. Typical values for sorbitol contents in apple juices range between 3 and 8 $\mathrm{g} / \mathrm{L}$. It is not used by microorganisms during the fermentation process, and it contributes to the palate fullness of ciders (Pollard et al., 1966). Differences for mean values of sorbitol contents were significant between years (Table 2).

Glycerol is a secondary product of alcohol ic fermentation and contributes to smoothness and roundness on the palate. No significant differences between years were found. Low levels or the absence of glycerol in fermented beverages is usually related to microbiological disorders caused by lactic acid bacteria (LAB), and has a negative influence on the sensory quality of ciders.

Carboxylic acids are important constituents of apple juice (malic, quinic, and shikimic acids) and cider (lactic, acetic, and succinic acids). Their concentrations determine $\mathrm{pH}$ and affect the flavor of ciders and their susceptibility to microbial spoilage. Malic acid, the main acid in apples, was present as a residual acid in all the analyzed ciders (contents found were lower than $200 \mathrm{mg} /$ $\mathrm{L}$, Table 2). This acid is converted into lactic acid, the major acid in natural ciders, by LAB (malolactic fermentation). This secondary fermentation decreases acidity/astringency and contributes positively to the microbiological stability of natural ciders. Quinic and shikimic acids are usually reduced to dihydroshikimic acid by $L A B$, and their concentrations decrease during cider maturation. Shikimic acid ranged from not detected (ND) to more than $40 \mathrm{mg} / \mathrm{l}$, these differences not being significant at the $5 \%$ level (Table 2). Succinic acid is the main carboxylic acid produced by yeasts in the course of al coholic fermentation. $\mathrm{H}$ igh values are related to a strong salty-bitter flavor. The highest contents were observed in the 1995 samples, and the lowest were found in the ciders from 1996.

Acetic acid formation may occur at all stages of cider making as a result of different microorganisms metabolizing a range of substrates. Traditionally, apple juice fermentation is carried out by the indigenous flora, and the formation of acetic acid by apiculate yeasts during the initial stages of fermentation is predominant in all the Asturian cider cellars analyzed elsewhere (Cabranes, 1994). During the maturation and storage of cider, LAB and acetic acid bacteria continue their activity, but only $3 \%$ of the cider analyzed showed acetic acid contents higher than $2.20 \mathrm{~g} / \mathrm{L}$, thus being unsuitable for consumption.

Volatile components play an important role in the quality of fermented beverages. The fusel alcohol fraction is made up of aliphatic and aromatic alcohols (namely, 1-propanol, isobutanol, isoamyl and active amyl alcohols, and 2-phenylethanol). Production of higher alcohols is influenced by the composition of the medium, the prefermentative clarification technique, and the fermentation process (temperature, aeration, yeast strain). Major volatile profiles are characterized by the presence of high levels of 2-phenylethanol and amyl alcohols (Table 3). Both are normal components in fermented beverages; the first is associated with floral and fragrant aromas (ASTM, 1985), while isoamyl and active amyl alcohols contribute to defining the round complex aroma of fermented beverages, if present in moderate amounts. The sum of the amyl alcohol contents was, in general, lower than $300 \mathrm{mg} / \mathrm{L}$, a value above which the sensory quality of fermented beverages can be negatively affected. The values found in Asturian natural ciders were in accordance with previous reports for English ciders (Pollard et al., 1966) but higher than those of French ciders (Leguérinel et al., 1987). The French cider-making process is characterized by prefermentative clarification and incompl ete fermentation, which may account for the lower levels of fusel alcohols observed in this product.

Levels for 1-propanol and isobutanol in Asturian natural cider varied widely. Mean values for 1-propanol 
Table 3. Major Volatile Compounds in Asturian Natural Cider (mg/L) ${ }^{a}$

\begin{tabular}{|c|c|c|c|c|c|c|c|c|c|c|}
\hline consumption season & & acetal dehyde & $\begin{array}{l}\text { ethyl } \\
\text { acetate }\end{array}$ & $\mathrm{MeOH}$ & 1-propanol & i-BuOH & 1-BuOH & amylics & $\begin{array}{c}\text { ethyl lactate + } \\
\text { hexanol }\end{array}$ & 2-phenylethanol \\
\hline \multirow[t]{4}{*}{$1995(n=18)$} & mean & $10.2^{\mathrm{a}}$ & $99.9^{b}$ & $99.4^{b}$ & $30.0^{c}$ & $26.0^{\mathrm{a}}$ & $4.8^{\mathrm{a}}$ & $152.5^{\mathrm{b}}$ & NA & NA \\
\hline & SD & 6.6 & 40.8 & 37.8 & 19.0 & 8.8 & 0.8 & 33.2 & NA & NA \\
\hline & $\max$ & 33.6 & 222.0 & 188.5 & 69.5 & 50.4 & 5.8 & 213.7 & NA & NA \\
\hline & $\min$ & 1.4 & 53.2 & 49.5 & 9.2 & 10.1 & 3.2 & 98.5 & NA & NA \\
\hline \multirow[t]{4}{*}{$1996(n=31)$} & mean & $28.2^{\mathrm{d}}$ & $108.1^{b}$ & $109.7^{b}$ & $19.5^{\mathrm{a}}$ & $39.5^{c}$ & $7.4^{c}$ & $181.5^{\mathrm{b}}$ & $131.2^{\mathrm{b}}$ & $99.1^{b}$ \\
\hline & SD & 19.0 & 46.2 & 51.3 & 12.7 & 19.8 & 5.2 & 63.6 & 55.6 & 45.7 \\
\hline & $\max$ & 91.4 & 203.1 & 248.1 & 71.4 & 103.4 & 30.0 & 290.8 & 298.0 & 188.7 \\
\hline & $\min$ & 7.6 & 40.7 & 23.8 & 7.3 & 8.4 & 1.6 & 72.3 & 49.9 & 29.6 \\
\hline \multirow[t]{4}{*}{$1997(n=25)$} & mean & $17.8^{\mathrm{a}}$ & $55.7^{a}$ & $34.1^{\mathrm{a}}$ & $12.4^{\mathrm{a}}$ & $27.2^{\mathrm{a}}$ & $3.5^{\mathrm{a}}$ & $120.6^{a}$ & $84.2^{\mathrm{a}}$ & $68.0^{a}$ \\
\hline & SD & 17.5 & 28.8 & 13.5 & 9.6 & 8.8 & 2.8 & 36.2 & 33.2 & 21.3 \\
\hline & $\max$ & 97.9 & 140.8 & 69.0 & 35.6 & 42.5 & 6.9 & 226.3 & 223.3 & 122.6 \\
\hline & $\min$ & 5.4 & 17.3 & 15.7 & ND & ND & ND & 64.8 & 45.9 & 36.6 \\
\hline \multirow[t]{4}{*}{$1998(n=20)$} & mean & $11.2^{\mathrm{a}}$ & $114.6^{b}$ & $118.5^{b}$ & $27.3^{c}$ & $34.8^{\mathrm{a}}$ & $6.1^{\mathrm{b}}$ & $173.0^{\mathrm{b}}$ & $148.5^{b}$ & $131.5^{c}$ \\
\hline & SD & 11.0 & 35.5 & 39.3 & 13.0 & 8.9 & 0.7 & 41.1 & 41.8 & 55.3 \\
\hline & $\max$ & 47.3 & 206.4 & 208.5 & 64.4 & 63.6 & 7.2 & 264.8 & 219.7 & 243.8 \\
\hline & $\min$ & 3.0 & 70.4 & 59.8 & 9.1 & 23.5 & 4.9 & 122.3 & 74.2 & 35.8 \\
\hline
\end{tabular}

${ }^{a}$ Results of the Duncan test. Values with the same superscript letter are not significantly different at the $5 \%$ confidence level. ND = not detected; NA = not analyzed.

were generally lower than those reported by Beech and Carr (1977) for English ciders made from single-variety apple juices, while those for isobutanol were higher in the Asturian natural ciders. In this sense, the existence of a strong dependence between the production of 1-propanol and the yeast strain is noteworthy. Higher levels of 1-propanol are formed by those strains unable to produce dihydrogen sulfide (Giudici and Kunkee, 1994). It should also be noted that this dependence is lower for isobutanol and amylic alcohols (Giudici, 1993). The positive influence of 1-propanol on the sensory assessment of foam characteristics has previously been ascertained (Mangas et al., 1999).

1-Butanol is a varietal characteristic, this alcohol being included in the primary aroma of apples. The content present in the apple fruit decreases during the fermentation of musts; only $4.2 \%$ of the samples presented values for this alcohol higher than $10 \mathrm{mg} / \mathrm{L}$ (Table 3). 1-Butanol contents were higher in ciders made from Asturian apples (1996 and 1998) than in those made from foreign apples (1995 and 1997).

Methanol is not a yeast fermentation product but is cleaved from pectins. Although it is not relevant to the flavor of cider, a negative influence on the foam characteristics has recently been established in a preliminary study (Mangas et al., 1999). The concentration of methanol differs widely between samples. The traditional cider-making process does not include a prefermentative clarification or keeving, with depectination of musts; thus, the influence of the raw material and the yeast strain on the concentration of methanol in Asturian natural cider seems evident, as observed in experimental fermentations of cider (Cabranes et al., 1997).

Acetaldehyde is the major component among the carbonyl compounds. It is produced during the initial steps of the fermentation process and subsequently metabolized or reduced. I ts concentration varied widely depending on several factors: aeration, $\mathrm{SO}_{2}$ level, yeast strains, and nutrient levels. Spanish regulations (BOE, 1979) permit the addition of sulfur dioxide (100 mg/L, maximum) for natural cider making, but fermentation is usually carried out without $\mathrm{SO}_{2}$. Only two samples presented contents of acetal dehyde higher than $80 \mathrm{mg} /$ $\mathrm{L}$, unpleasant from the sensory point of view. Samples from the 1996 period presented the highest values, while no significant differences were found among the other three years considered.
Another interesting characteristic found in Asturian natural cider was the relatively high concentration of ethyl acetate compared to that in French ciders. This value is usually related to the cider-making process, which in Asturias favors the increase in volatile acidity in natural cider. Compared to the French process, in Asturias the must is obtained by slow pressing (2-3 days), without the addition of yeasts or sulfite, fermentation to dryness, and maturation in barrels without air for a short period of months. In France the fermentation process is slowed to obtain a final sweet product. F urthermore, the occasional use of pectolytic enzymes for cider making in France, which reduces the concentration of esters, especially acetates (Schreier et al., 1978), may be responsible for the lower contents found in this cider. However, the pressing technology also has an important influence on the volatile profile of ciders, as we were able to ascertain when slow and fast pressings were compared (Mangas et al., 1993). Ethyl acetate is usually related to the rough character of some traditionally made ciders, al though it is also associated with fresh and fruity aromas (ASTM, 1985). However, as far as we ascertained by sensory analysis, there was no clear relation between the level of ethyl acetate and the acceptability of ciders.

Multivariate Analysis. A partial least-squares procedure was employed to discriminate natural ciders elaborated from Asturian cider apples (even class) from those elaborated from Galician and F rench apples (odd class). Multivariate regression was carried out using the defined binary response as criterion variable and the 22 chemical variables as predictor variables; two samples belonging to the $\mathrm{E}$ category were detected as leverage points and removed from the data matrix. A crossvalidation procedure was carried out with three groups for cancellation. The cross-validated explained variance (CVEV) showed a maximum value (71.3\%) with three latent variables, the square of the multiple linear correlation coefficient $\left(R^{2}\right)$ being $80 \%$. The most relevant variables were as follows: succinic acid > total polyphe nols $>$ methanol > 2-phenylethanol, malic acid. Figure 1 shows two Box-Whisker plots using the PLS variable predicted by the PLSR-1 model with three latent variables. From the mathematical model computed, it is possible to discriminate between ciders made from Asturian or foreign apples, although more analyses must be made to characterize the Asturian natural ciders on the basis of the origin of the raw material. 


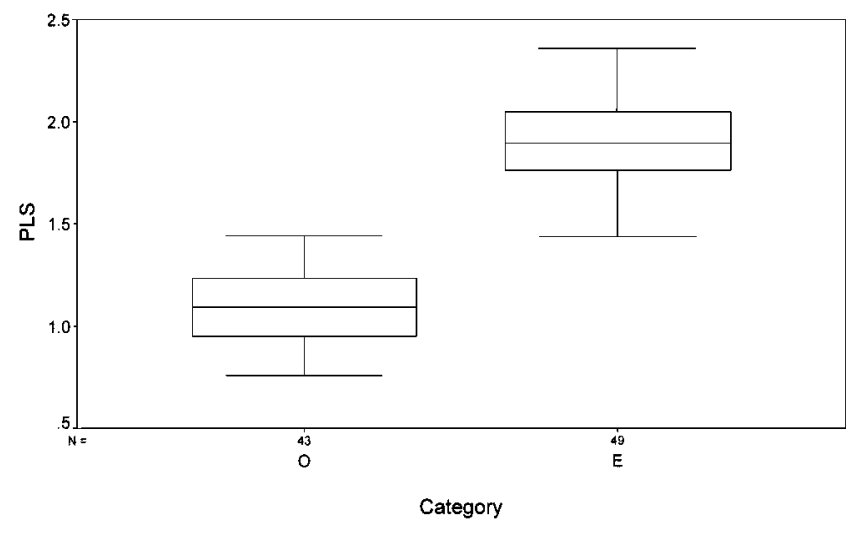

Figure 1. Box-Whisker plots using the PLS variable O: odd class; E: even class.

\section{CONCLUSIONS}

The results of this paper describe Asturian natural cider in terms of its chemical composition. Some of the typical characteristics of this product are the relatively high volatile acidity and concentrations of fusel alcohols, and the presence of malic acid in residual quantities. The application of multivariate modeling techniques, such as PLSR-1, along with determination of the chemical composition allowed ciders made from Asturian or foreign apples to be differentiated, which could be used for characterization purposes on the basis of the origin of the raw material.

\section{ACKNOWLEDGMENT}

We thank the Asociación de Lagareros Asturianos (ALA) (Association of Asturian Cider Makers) for providing the samples analyzed.

\section{LITERATURE CITED}

AOAC. Beverages: Wines. In Official Methods of Analysis of the Association of Official Analytical Chemists; Williams, S., Ed.; AOAC: Arlington, VA, 1984; pp 220-230.

ASTM Data Series: Atlas of odor character profiles; ASTM Data Series DS 61; American Society for Testing and Materials: Philadel phia, 1985.

Beech, F. W.; Carr, J. G. Cider and Perry. In Alcoholic Beverages; Rose, A. H., Ed.; Academic Press: London, 1977; Vol. I.

Blanco, D.; Gutiérrez, M. D.; Mangas, J . J .; Noval, A. Determination of sugars and alcohols in apple juice and cider by HPLC. Chromatographia 1988, 25, 701-706.

Blanco Gomis, D.; Gutiérrez M. D.; Morán, M. J .; Moreno, J .; Dapena, E.; Cabranes, C.; J. Mangas Alonso. Analytical control of cider production by two technological methods. J . Inst. Brew. 1991, 97, 453-456.

BOE, No. 206, Madrid, Aug 28, 1979.

Cabranes, C. Fermentaciones espontáneas einducidas en sidra natural Asturiana (Spontaneous and induced fermentations in Asturian natural cider). Ph.D. thesis, University of Oviedo, Spain, 1994.

Cabranes, C.; Mangas, J J J .; Blanco, D. Selection and biochemical characterization of Saccharomyces cerevisiae and Kloeckera apiculata strains isol ated from Spanish cider. J . Inst. Brew. 1997, 103, 165-169.

Cabranes, C.; Moreno, J .; Mangas, J J J . Dynamics of yeast populations during cider fermentation in the Asturian region of Spain. Appl. Environ. Microbiol. 1990, 56, 38813884.
Cabranes, C.; Moreno, J .; Mangas, J. J . Aspectos microbiológi cos y bioquími cos de la el aboración de sidra natural en lagares asturianos (Microbiological and biochemical aspects of cider-making in Asturian cellars). Alimentaria 1991, April, 63-69.

Forina, M.; Leardi, R.; Armanino, C.; Lanteri, S. PARVUS. An extendable package of programs for data exploration, classification and correlation; Elsevier: Amsterdam, 1988.

Giudici, P.; Kunkee, R. E. The effect of nitrogen defficieny and sulfur-containing amino acids on the reduction of sulfate to hydrogen sulfide by wine yeasts. Am. J . Enol. Vitic. 1994, 45, 107-112.

Giudici, P.; Zambonelli, C.; Kunkee, R. E. Increased production of n-propanol in wine by yeast strains having an impaired ability to form hydrogen sulfide. Am. J . Enol. Vitic. 1993, $44,17-21$.

IFR. Análisis de subsectores: sidra (Analyses of sub-sectors: cider). In El sector de las bebidas en Asturias (The drinks sector in Asturias); I nstituto de F omento Regional (I nstitute for Regional Promotion): Principado de Asturias, 1997.

Lea, A. G. H. Cidermaking. In Fermented beverage production; Lea, A. G. H., Piggott, J. R., Eds.; Blackie Academic \& Professional: London, 1995.

Lea, A. G. H.; Beech, F. W. Phenolics of ciders: the effect of cultural conditions. J . Sci. Food Agric. 1978, 29, 484-492.

Lea, A. G. H.; Timberlake, C. F. The phenolics of cider. 1. Procyanidins. J . Sci. Food Agric. 1974, 25, 1537-1545.

Lee, H. S.; Wrolstad, R. E. Detection of adulteration in apple juices. In Adulteration of fruit juice beverages; Nagy, S., Attaway J. A., Rhodes M. E., Eds.; Marcel Dekker: New York and Basel, 1988; pp 343-376.

Leguérinel, I.; Cléret, J . J .; Bourgeois, C. M.; Mafart, P. Essai d'évaluation des characteristiques organoleptiques des cidres par analyses instrumentales (Tentatives of sensory evaluation of ciders by intrumental analysis). Sci. Aliments 1987, 7, 223-239.

Mangas, J . J .; Cabranes, C.; Moreno, J .; Blanco Gomis, D. Influence of cider-making technology on cider taste. Lebensm.-Wiss.-Technol. 1994, 27, 583-586.

Mangas J .; González MaP.; Blanco D. I nfluence of cider-making technology on low-boiling-point volatile compounds. Z. Lebensm-U nters.-F orsch. 1993, 197, 522-524.

Mangas, J . J .; Moreno, J .; Picinelli, A.; Blanco, D. Characterization of cider apple fruits according to their degree of ripening. A chemometric approach. J . Agric. Food Chem. 1998, 46, 4174-4178.

Mangas, J . J .; Moreno, J .; Rodríguez, R.; Picinelli, A.; Suárez, $B$. The analysis of polysaccharides in cider. Their effect on sensory foaming properties. J . Agric. Food Chem. 1999, 47, 152-156.

Montreau, F. Sur le dosage des composés phénol iques totaux dans les vins par la méthode Folin-Ciocalteu (Total phenol analysis in wines by the F olin-Ciocalteu method). Connaiss. Vigne Vin 1972, 6, 397-404.

Picinelli, A. Evaluación sensorial de sidra natural (Sensory assessment of natural cider). Consejería de Agricultura del Principado de Asturias: Oviedo, 1999.

Pollard, A.; Kieser, M. E.; Beech, F. W. Factors influencing the flavour of cider: the effect of fermentation treatments on fusel oil production. J. Appl. Bacteriol. 1966, 29, 253259.

Salih, A. G.; Le Quéré, J -M.; Drilleau; J .-F., Moreno Fernández, J . Lactic acid bacteria and malolactic fermentation in the manufacture of Spanish cider. J . Inst. Brew. 1990, 96, 369-372.

Schreier, P.; Drawert, F.; Steiger, G.; Mick, W. Effect of enzyme treatment of apple pulp with a commercial pectinase and cellulase on the volatiles of juice. J. Food Sci. 1978, 43, 1797-1800.

SPSS Advanced Statistics 6.1.. Marija J . Noruŝis/SPSS Inc., Chicago, 1994. 
Whiting, G. C. Acetification in ciders and perries. J . Inst. Brew. 1973, 79, 218-226.

Williams, A. A. Flavour effects of ethanol in alcoholic beverages. Flavour Ind. 1972, Dec, 604-607.

Williams, A. A.; May, H. V. Examination of an extract of cider volatiles using both electron impact and chemical ionization gas chromatography-mass spectrometry. J . Inst. Brew. 1981, 87, 372-375.

Williams, A. A.; Tucknott, O. G. Volatile constituents of fermented cider. I.- Draught dry cider blend. J . Sci. Food Agric. 1971, 22, 264-269.

Williams, A. A.; Tucknott, O. G. The volatile aroma constituents of fermented ciders: minor neutral components from the fermentation of Sweet-Coppin apple juice. J . Sci. Food Agric. 1978, 29, 381-397.

Received for review November 24, 1999. Revised manuscript received J une 20, 2000. Accepted J une 26, 2000. We are indebted to CICYT (Grant ALI96-1219-CO2-01) and the Principado de Asturias (Asturian Regional Administration) for financial support.

J F 991284D 